Original Research Article

\title{
Effect of intravenous infusion of magnesium sulphate on postoperative analgesia in patients undergoing arthroscopic knee surgeries under spinal anaesthesia
}

\author{
Revi N., Mithun Raju P.*, Mohsin Mohammed Ali
}

Department of Anaesthesiology, Amala Institute of Medical Sciences, Thrissur, Kerala 680555, India

Received: 11 December 2016 Accepted: 02 January 2017

\section{*Correspondence to:}

Dr. Mithun Raju P.,

Email:

mithunraju@hotmail.com

Copyright: (C) the author(s), publisher and licensee Medip Academy. This is an openaccess article distributed under the terms of the Creative Commons Attribution NonCommercial License, which permits unrestricted noncommercial use, distribution, and reproduction in any medium, provided the original work is properly cited.

\begin{abstract}
Background: Magnesium sulphate is being used for postoperative pain relief intravenously, intrathecally and epidurally. Currently, it is also gaining popularity as an adjuvant in blocks. The objective of the study was aimed at the postoperative analgesic effects of magnesium sulphate when given as intravenous infusion in patients undergoing arthroscopic knee surgeries under spinal anaesthesia and to compare the postoperative analgesic effects of magnesium sulphate infusion in a study cohort who received magnesium sulphate with the control cohort who were not given magnesium sulphate and underwent arthroscopic knee surgeries under spinal anaesthesia.
\end{abstract}

Methods: After obtaining ethical committee clearance and consent from the patients, 31 patients each were placed in study cohort and control cohort. Spinal anaesthesia was administered in the lateral decubitus position through the L3-4 or L4-5 interspace. Hyperbaric bupivacaine $0.5 \%$ solution with fentanyl $20 \mu \mathrm{g}$ was injected intrathecally. After spinal anaesthesia, patients received magnesium sulphate $50 \mathrm{mg} / \mathrm{kg}$ for $15 \mathrm{~min}$ and then $15 \mathrm{mg} / \mathrm{kg} / \mathrm{hr}$ by continuous intravenous infusion until the end of surgery. The other group did not receive magnesium sulphate infusion. Postoperative pain scores and postoperative analgesic consumption were the primary end points.

Results: The results of the study reveal the efficacy of perioperative intravenous infusion of magnesium sulphate in prolonging the spinal block as well as reducing the postoperative pain scores without hemodynamic variability or side effects.

Conclusions: Post-operative pain and analgesic consumption was reduced with the use of intravenous magnesium following spinal anaesthesia.

Keywords: Cohort study, Intravenous infusion, Intravenous infusion, Magnesium sulphate

\section{INTRODUCTION}

Spinal anaesthesia is a popular and time-tested regional anaesthetic technique with good safety profile and high success rate but has a limited duration of action. In recent times, the use of intrathecal adjuvants with sub therapeutic doses of local anaesthetic has become popular as they have a synergistic effect, boosts analgesia, extends the period and rises the intensity of block, provides better patient satisfaction with fewer complications. ${ }^{1}$ Postoperative pain following arthroscopic knee surgeries is usually moderate to severe in nature. For early rehabilitation and functional recovery, adequate postoperative pain management and satisfactory analgesia is important.

Magnesium, a physiological calcium antagonist by blocking NMDA receptors in a voltage dependent manner, abolishes hypersensitisation and produces a reduction of NMDA induced currents. Intrathecal magnesium sulphate has shown to prolong analgesic effects of opiods in spinal anaesthesia as a non competitive NMDA antagonist in the first randomized human study. ${ }^{2}$ During general anaesthesia, Magnesium sulphate infusion reduced the anaesthetic requirement and postoperative pain and analgesic consumption as demonstrated by numerous clinical trials. ${ }^{3}$ Magnesium 
sulphate is being used for postoperative pain relief intravenously, intrathecally and epidurally. Currently, it is also gaining popularity as an adjuvant in blocks. The effects of magnesium sulphate infusion during spinal anaesthesia have been investigated only in a limited number of studies. ${ }^{4}$ The effect on postoperative pain and analgesic consumption by systemic magnesium sulphate during spinal anaesthesia has not been fully determined yet.

Thus, it was hypothesized that use of intravenous infusion of magnesium sulphate may have an effect on the duration of action of intrathecal bupivacaine and block characteristics and this study was planned to evaluate the effect of an intravenous infusion of magnesium sulphate on postoperative pain and analgesic consumption in patients undergoing arthroscopic knee surgeries under spinal anaesthesia.

\section{METHODS}

A prospective cohort study was designed in department of anaesthesiology, Amala Institute of Medical Sciences, Thrissur from December 2014 to June 2016. This study was approved by Institutional Ethics committee of Amala Institute of Medical Sciences. Sixty two patients belonging to ASA category I and II, undergoing arthroscopic knee surgeries under spinal anaesthesia at Amala Institute of Medical Sciences, Thrissur.

Patients aged between 18 to 65 years belonging to ASA category I and II were included. From the patients selected for the study following patients were excluded.

a) Patients having coexisting systemic disorders like neuromuscular diseases, neuronal degenerative disorders, cardiovascular, hepatic or renal dysfunction, bleeding and haematological disorders.

b) Patients with past history of allergies to the study drugs, on analgesics or calcium channel blockers or with a history of opioid and analgesic abuse.

c) Patients having contraindications to central neuraxial blockade.

d) Patient refusal.

Sample size was calculated following the study by Hwang et al based on intravenous infusion of magnesium sulphate improving postoperative analgesia in patients undergoing total hip arthroplasty with slight modifications. ${ }^{4}$

$$
\mathrm{n}=\frac{\left({S_{1}}^{2}+S_{2}{ }^{2}\right) \times\left(Z_{1-\frac{\alpha}{2}}+Z_{1}-\beta\right)}{\left(X_{1}-X_{2}\right)^{2}}
$$

Where $\mathrm{n}$ is the sample size.

$\mathrm{X}_{1}$ is the mean for the time to first pain in mins in patients who received intravenous magnesium sulphate.
$S_{1}$ is the standard deviation for the time to first pain in patients who received intravenous magnesium sulphate.

$\mathrm{X}_{2}$ is the mean time to first pain in mins in patients who did not receive magnesium sulphate infusion.

$\mathrm{S}_{2}$ is the standard deviation for the time to first pain in patients who did not receive magnesium sulphate infusion.

$\mathrm{Z}_{1}-\alpha / 2=1.64$ at $\alpha=5 \%$.

The sample size calculated for each group was 31 .

All patients who were posted for arthroscopic knee surgeries under spinal anaesthesia were consecutively placed in the study cohort and comparative cohort till the sample size was obtained. All patients who received intravenous magnesium sulphate formed the study cohort (Mg group) and all patients who were not given intravenous magnesium sulphate formed the comparative cohort (Non $\mathrm{Mg}$ group). Study protocol was explained in detail to all patients and written informed consent obtained prior to the study. 31 patients each were placed in study cohort and comparative cohort. Patients were shifted to the operating theatre after premedication with intravenous midazolam $0.03 \mathrm{mg} / \mathrm{kg}$. Normal saline 500 $\mathrm{ml}$ was given over $15 \mathrm{~min}$, mandatory monitors including ECG, non-invasive blood pressure and pulse oximeter were connected and initial vitals recorded. Spinal anaesthesia was administered in the lateral decubitus position through the L3- L4 or L4-L5 interspace. A 25 G Quincke needle was used to puncture the dura, following which hyperbaric bupivacaine $0.5 \%$ solution (bupivacaine dose was decided based on height; height $<155 \mathrm{~cm}=12 \mathrm{mg} ; 155-170 \mathrm{~cm}=13 \mathrm{mg} ; 170-180 \mathrm{~cm}=14$ $\mathrm{mg} ; \geq 180 \mathrm{~cm}=15 \mathrm{mg}$ ) with Fentanyl $20 \mu \mathrm{g}$ was injected intrathecally.

Pinprick testing was performed to assess the height and regression of spinal sensory block using a sterile needle compared to a non-anaesthetised part of the body so the patient can perceive the difference. Motor block onset and duration was decided as the time to achieve modified Bromage scale grade 2 i.e., able to move feet but inability to rise extended leg and move knee. Pre and intraoperative administration of magnesium sulphate (50 $\mathrm{mg} / \mathrm{kg}$ bolus and maintenance of $15 \mathrm{mg} / \mathrm{kg} / \mathrm{hr}$ ) in gynaecology patients receiving TIVA (Total Intravenous Anaesthesia) reduced rocuronium requirement and improved the quality of postoperative analgesia without any significant side-effects.

Accordingly, in the present study, after spinal anaesthesia, magnesium sulphate was administered to the patients in the Magnesium group ( $\mathrm{Mg}$ group) or study cohort $(\mathrm{n}=31)$ as $50 \mathrm{mg} / \mathrm{kg}$ for $15 \mathrm{~min}$ and then 15 $\mathrm{mg} / \mathrm{kg} / \mathrm{hr}$ by continuous intravenous infusion until the end of surgery. Patients in the Non Magnesium group (Non $\mathrm{Mg}$ group) or control group $(\mathrm{n}=31)$ did not receive 
Magnesium Sulphate infusion. Postoperative pain scores and postoperative analgesic consumption were the primary end points.

If the systolic blood pressure dropped to below $90 \mathrm{~mm}$ $\mathrm{Hg}$ or if mean arterial pressure decreased more than $20 \%$ from baseline, ephedrine 3 to $6 \mathrm{mg}$ was given intravenously and if the heart rate decreased to less than 45 beats/min, intravenous atropine $0.6 \mathrm{mg}$ was administered.

\section{Statistical analysis}

Data were analyzed using the statistical software Statistical Package for Social Sciences (SPSS) and presented in mean \pm standard deviation. Baseline characteristics of study subjects were explained in terms of frequency, percentage, mean and standard deviation. The vital signs (heart rate, respiratory rate and non invasive blood pressure), need for first analgesic requirement, total tramadol consumption and the postoperative pain scores in both the groups were compared using Student ' $t$ ' test. The incidence and severity of nausea, vomiting and shivering in both the groups were compared with the help of Chi square test. The level of significance was estimated with $95 \%$ confidence intervals and $\mathrm{P}$ value $<0.05$.

\section{RESULTS}

Sixty two patients belonging to ASA physical status I and II, aged between 18 to 65 years, scheduled for arthroscopic knee surgeries under spinal anaesthesia were included in the study. Data of each patient were statistically analysed.

Demographic profiles of the patients are presented in Table 1. No significant difference was found between the two groups in terms of age, gender, height, weight, ASA grade or duration of surgery and the demographic profile was similar in both the groups.

Table 1: Demographic profile.

\begin{tabular}{|lll|}
\hline $\begin{array}{l}\text { Patients } \\
\text { characteristics }\end{array}$ & $\begin{array}{l}\text { Mg Group } \\
(\mathbf{n = 3 1})\end{array}$ & $\begin{array}{l}\text { Non Mg Group } \\
(\mathbf{n = 3 1})\end{array}$ \\
\hline Age (years) & $35.29 \pm 10.885$ & $34.61 \pm 9.684$ \\
\hline Sex (M:F) & $28: 3$ & $23: 8$ \\
\hline Weight (Kg) & $58.00 \pm 5.848$ & $57.16 \pm 6.383$ \\
\hline Height (cm) & $168.03 \pm 7.468$ & $168.77 \pm 7.003$ \\
\hline ASA grade I / II & $28 / 3$ & $27 / 4$ \\
\hline $\begin{array}{l}\text { Duration of } \\
\text { surgery (min) }\end{array}$ & $103 \pm 9.03$ & $103.55 \pm 9.50$ \\
\hline
\end{tabular}

No technical or procedural failure related to spinal anaesthesia occurred and all cases were completed as planned. Mean block height was T8 in two groups, administered dose of bupivacaine was similar between the two groups $(13.52 \pm 0.50 \mathrm{mg}$ in $\mathrm{Mg}$ group and
$13.55 \pm 0.56$ in Non $\mathrm{Mg}$ group). Time for regression of sensory block to $\mathrm{T} 12 / \mathrm{L} 1$ was $193.55 \pm 6.08 \mathrm{~min}(\mathrm{Mg}$ group) and 155.81 $\pm 5.016 \mathrm{~min}$ (Non $\mathrm{Mg}$ Group) ( $\mathrm{P}=$ 0.001 ). Mean duration of motor block was longer in $\mathrm{Mg}$ group (155.94 $\pm 5.176 \mathrm{~min})$ compared with Non $\mathrm{Mg}$ Group (122.45 $\pm 6.191 \mathrm{~min})(\mathrm{P}=0.001)$.

Table 2: Characteristics of block.

\begin{tabular}{|lll|}
\hline Characteristic & $\begin{array}{l}\text { Mg group } \\
(\mathbf{n = 3 1})\end{array}$ & $\begin{array}{l}\text { Non Mg } \\
\text { Group }(\mathbf{n}=\mathbf{3 1})\end{array}$ \\
\hline $\begin{array}{l}\text { Height of spinal } \\
\text { block (level) }\end{array}$ & $\mathrm{T} 8$ & $\mathrm{~T} 8$ \\
\hline $\begin{array}{l}\text { Mean dose of } \\
\text { bupivacaine (mg) }\end{array}$ & $13.52 \pm 0.50$ & $13.55 \pm 0.56$ \\
\hline $\begin{array}{l}\text { Onset of sensory } \\
\text { blockade (min) }\end{array}$ & $7.45 \pm 0.506$ & $7.68 \pm 0.475$ \\
\hline $\begin{array}{l}\text { Sensory block } \\
\text { duration (min) } \\
\text { (Regression to } \\
\text { T12/L1) }\end{array}$ & $193.55 \pm 6.08$ & $155.81 \pm 5.016$ \\
\hline $\begin{array}{l}\text { Onset of motor } \\
\text { blockade (min) }\end{array}$ & $9.52 \pm 1.06$ & $9.0 \pm 0.87$ \\
\hline $\begin{array}{l}\text { Motor block } \\
\text { duration (min) }\end{array}$ & $155.94 \pm 5.176$ & $122.45 \pm 6.191$ \\
\hline
\end{tabular}

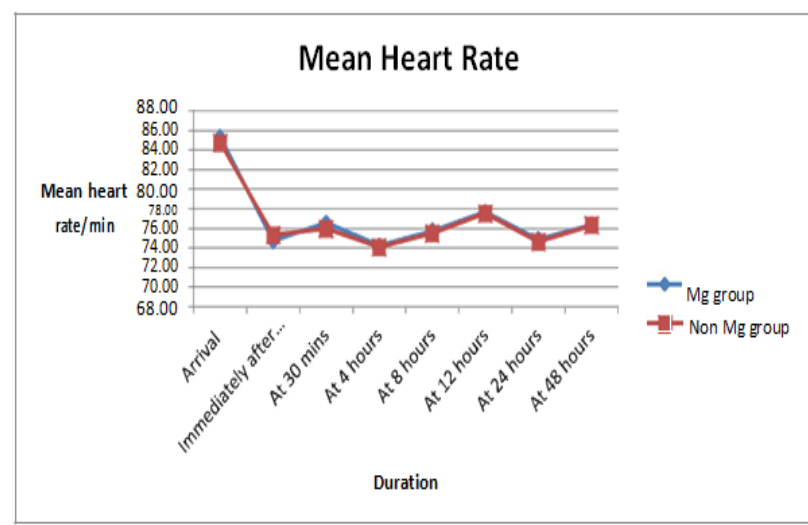

Figure 1: Hemodynamic parameters.

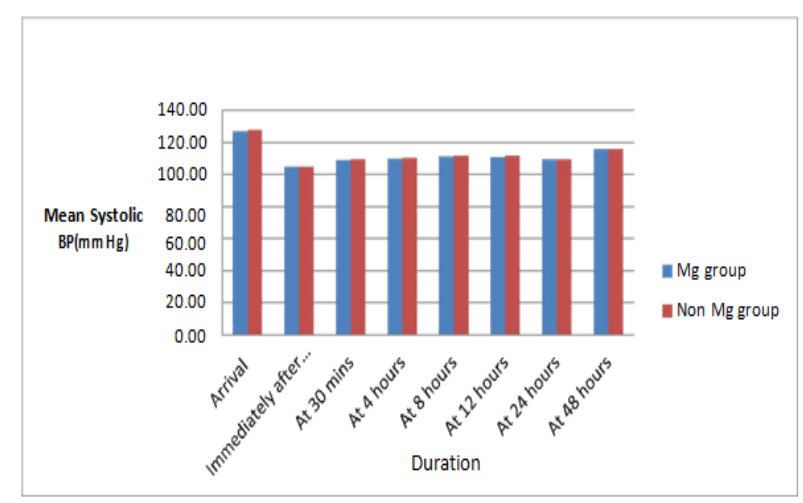

Figure 2: Mean systolic BP.

Hemodynamic parameters were similar in two groups and statistically not significant. 3 patients in $\mathrm{Mg}$ group 
and 4 patients in Non Mg Group developed hypotension, 1 patient in $\mathrm{Mg}$ Group developed bradycardia during surgery. According to the study protocol, ephedrine $6 \mathrm{mg}$ and atropine $0.6 \mathrm{mg}$ were administered and arterial pressure and heart rate normalized.

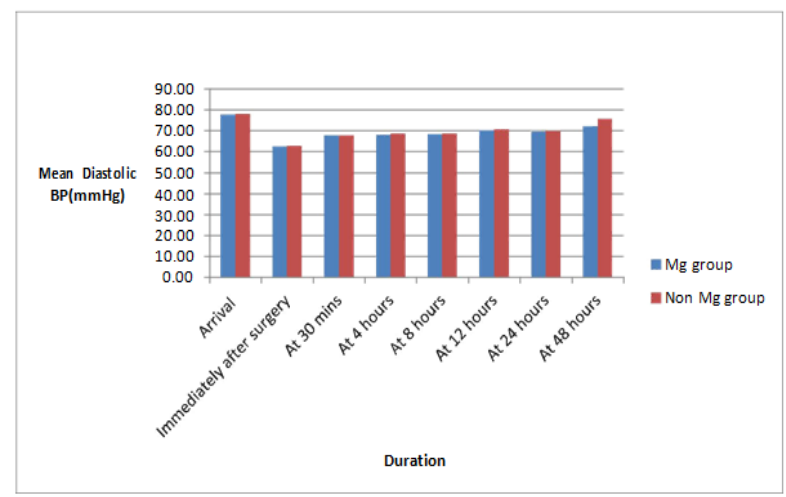

Figure 3: Mean diastolic BP.

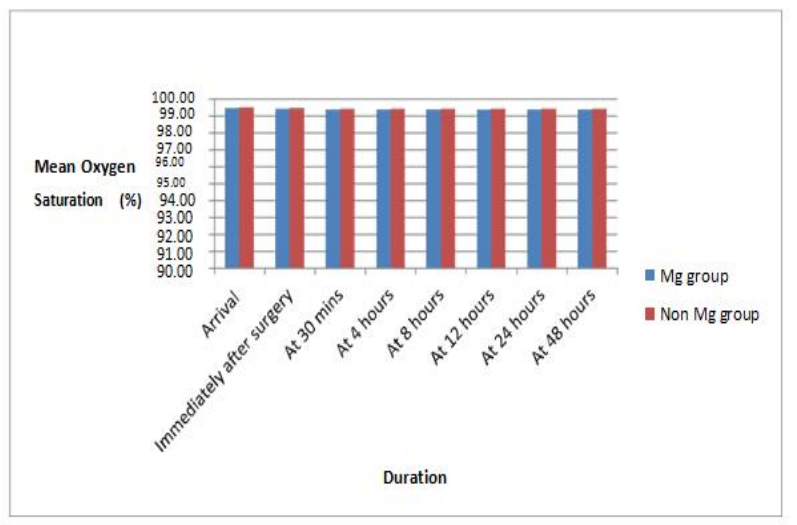

Figure 4: Mean oxygen saturation.

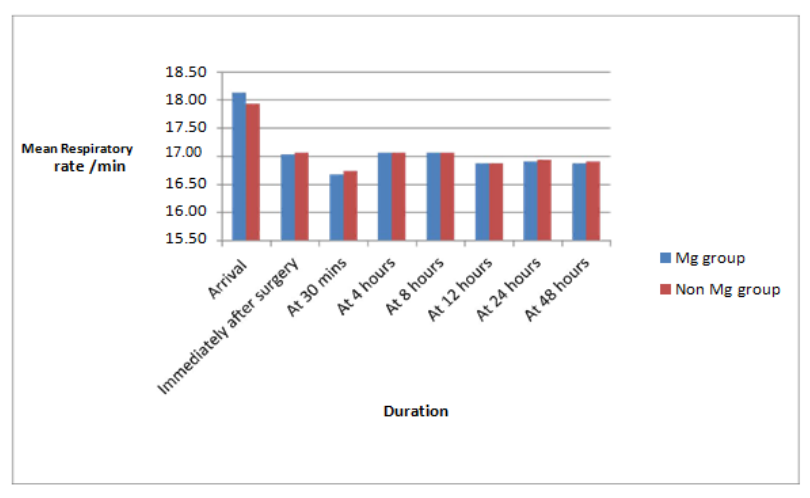

Figure 5: Mean respiratory rate.

Significant hemodynamic depression was not seen in our study and hemodynamic variability did not differ from the control group. Prehydration with $500 \mathrm{ml}$ of Normal saline solution was given considering the negative inotropic effect of magnesium sulphate and then the magnesium sulphate bolus dose was infused over $15 \mathrm{~min}$, which is why no significant hypotension developed after administering the bolus dose (even though magnesium sulphate has vasodilatory effects).

Table 3: Need for first analgesic requirement.

\begin{tabular}{|llll|}
\hline & Mg group & $\begin{array}{l}\text { Non Mg } \\
\text { group }\end{array}$ & $\begin{array}{l}\mathbf{p} \\
\text { value }\end{array}$ \\
\hline $\begin{array}{l}\text { Need for first } \\
\text { analgesic } \\
\text { requirement/ } \\
\begin{array}{l}\text { Time to first } \\
\text { pain (min) }\end{array}\end{array}$ & $289.67 \pm 8.36$ & $231.19 \pm 2.53$ & 0.001 \\
\hline
\end{tabular}

Need for first analgesic requirement was after $289.67 \pm 8.36 \mathrm{~min}$ in $\mathrm{Mg}$ group and $231.19 \pm 2.53 \mathrm{~min}$ in the Non $\mathrm{Mg}$ group $(\mathrm{P}=0.001)$ which is presented in Table 3.

Table 4: Postoperative pain scores.

\begin{tabular}{|c|c|c|c|}
\hline \multirow{2}{*}{ Duration } & \multicolumn{2}{|c|}{$\begin{array}{l}\text { Mean postoperative pain } \\
\text { score (VAS) }\end{array}$} & \multirow{2}{*}{$\begin{array}{l}P \\
\text { value }\end{array}$} \\
\hline & $\begin{array}{l}\text { Mg group } \\
(\mathrm{n}=31)\end{array}$ & $\begin{array}{l}\text { Non } \mathrm{Mg} \text { group } \\
(\mathrm{n}=31)\end{array}$ & \\
\hline At 4 hours & $0.87 \pm 0.34$ & $3.35 \pm 0.66$ & 0.001 \\
\hline At 8 hours & $0.58 \pm 0.50$ & $2.61 \pm 1.08$ & 0.001 \\
\hline At 12 hours & $1.58 \pm 0.50$ & $3.42 \pm 0.95$ & 0.001 \\
\hline At 24 hours & $0.84 \pm 0.30$ & $3.03 \pm 1.04$ & 0.001 \\
\hline At 48 hours & $2.81 \pm 0.40$ & $2.94 \pm 0.25$ & $>0.05$ \\
\hline
\end{tabular}

Postoperative pain scores assessed by visual analogue scale was less in Mg group till 24 hours (Table 4). The values were significantly different. The pain scores were similar in both the groups between 24 to 48 hours.

Table 5: Mean dosage of tramadol consumption.

\begin{tabular}{|llll|}
\hline & Mg group & $\begin{array}{l}\text { Non Mg } \\
\text { group }\end{array}$ & $\begin{array}{l}\mathbf{p} \\
\text { value }\end{array}$ \\
\hline$<24$ hours & $251.61 \pm 50.80$ & $393.55 \pm 24.97$ & 0.001 \\
\hline $\begin{array}{l}>24 \text { hours }- \\
\text { 48 hours }\end{array}$ & 300 & 300 & \\
\hline
\end{tabular}

Table 6: Rescue analgesia required in patients.

\begin{tabular}{|c|c|c|c|c|}
\hline & \multicolumn{2}{|c|}{ Rescue analgesia } & \multirow{2}{*}{$\begin{array}{l}\text { Relative } \\
\text { Risk } \\
\text { (95\% CI) }\end{array}$} & \multirow{2}{*}{$\begin{array}{l}\mathbf{P} \\
\text { value }\end{array}$} \\
\hline & Given & $\begin{array}{l}\text { Not } \\
\text { given }\end{array}$ & & \\
\hline $\begin{array}{l}\text { Mg Group } \\
(\mathrm{n}=31)\end{array}$ & $\begin{array}{l}1 \\
(3.2 \%)\end{array}$ & $\begin{array}{l}30 \\
(96.8 \%)\end{array}$ & \multirow{2}{*}{$\begin{array}{l}0.25 \\
(0.03- \\
2.11)\end{array}$} & \multirow[b]{2}{*}{$<0.05$} \\
\hline $\begin{array}{l}\text { Non } \mathrm{Mg} \\
\text { Group } \\
(\mathrm{n}=31)\end{array}$ & $\begin{array}{l}4 \\
(12.9 \%)\end{array}$ & $\begin{array}{l}27 \\
(87.1 \%)\end{array}$ & & \\
\hline
\end{tabular}

Mean dosage of Tramadol needed in first 24 hrs was less in $\mathrm{Mg}$ group compared to the Non $\mathrm{Mg}$ group $(251.61 \pm 50.80 \mathrm{mg}$ versus $393.55 \pm 24.97 \mathrm{mg}, \mathrm{P}=0.001)$ (Table 5). There was no change in Tramadol dosing required between 24 to 48 hours. One patient in $\mathrm{Mg}$ 
group and 4 patients in Non $\mathrm{Mg}$ group required rescue analgesia which is shown in Table 6 and morphine 4.5 $\mathrm{mg}$ intramuscularly $(\mathrm{P}<0.05)$.

The incidences of postoperative nausea, vomiting and shivering are given in Table 7. The incidence of postoperative nausea and vomiting after surgery were similar in the two groups. There was no statistically significant difference in the incidence of shivering between the two groups.

Table 7: Postoperative nausea, vomiting and shivering.

\begin{tabular}{|c|c|c|c|c|c|c|}
\hline & \multicolumn{2}{|c|}{$\begin{array}{l}\text { Postoperative nausea and } \\
\text { vomiting }\end{array}$} & \multirow{2}{*}{ P value } & \multicolumn{2}{|c|}{ Postoperative shivering } & \multirow{2}{*}{$P$ value } \\
\hline & $\begin{array}{l}\text { Study Group } \\
(\mathrm{n}=31)\end{array}$ & $\begin{array}{l}\text { Control } \\
\text { Group }(\mathrm{n}=31)\end{array}$ & & $\begin{array}{l}\text { Study Group } \\
(\mathrm{n}=\mathbf{3 1})\end{array}$ & $\begin{array}{l}\text { Control Group } \\
(\mathbf{n}=31)\end{array}$ & \\
\hline Immediately after surgery & 0 & 0 & \multirow{7}{*}{$>0.05$} & 0 & 0 & \multirow{7}{*}{$>0.05$} \\
\hline At 30 mins & 0 & 0 & & 0 & 0 & \\
\hline At 4 hours & 2 & 2 & & 1 & 2 & \\
\hline At 8 hours & 0 & 0 & & 0 & 0 & \\
\hline At 12 hours & 1 & 2 & & 0 & 0 & \\
\hline At 24 hours & 0 & 0 & & 0 & 0 & \\
\hline At 48 hours & 0 & 0 & & 0 & 0 & \\
\hline
\end{tabular}

\section{DISCUSSION}

Patients who fulfilled selection criteria were selected for the study. A total of sixty two patients who belonged to ASA physical status I and II, with age between 18 to 65 years and scheduled for arthroscopic knee surgeries under spinal anaesthesia.

There was no difference in the onset of sensory and motor block between the two groups were shown from the results of Table 2. Malleswaran et al have postulated that delayed onset of block might be because of the changes in $\mathrm{pH}$ and baricity of local anaesthetic solution with the addition of intrathecal magnesium sulphate. ${ }^{5}$ With intravenous administration of magnesium sulphate, the same mechanism does not work and further research is needed to evaluate this aspect.

Time for regression of sensory block to T12/L1 found in this study was similar to the study done by Agarwal and coworkers, where time for regression of sensory block to $\mathrm{T} 12 / \mathrm{L} 1$ was $206.88 \pm 20.96 \mathrm{~min}$ (Group $\mathrm{Mg}$ ) and 163.88 \pm 15.46 min (Group Non Mg) $(\mathrm{P}=0.000)$. ${ }^{6}$ Mean duration of motor block was longer in $\mathrm{Mg}$ group (160.63 \pm 17.76 min) compared with Non Mg Group (130.12 \pm 20.70 $\min )(\mathrm{P}=0.000)$. Kahraman $\mathrm{F}$ and Eroglu A also found that in Group $\mathrm{Mg}$, sensorial block regression was longer than that in Group Non Mg (175 \pm 39 versus $136 \pm 32$ min) $(\mathrm{P}<0.01)^{\text {? }}$

Sensory block has been found to be increased with the use of magnesium sulphate. Anti-nociception property is by decreasing calcium mediated release of neurotransmitters which are implicated in nociception and inflammation. The reason for a decrease in post nociception central sensitization of pain is said to be blocking of NMDA receptors. ${ }^{8}$ Direct depression of excitability of muscle fiber membrane and reduction of acetylcholine release from motor nerve terminals produces motor blockade. ${ }^{4}$

The results of hemodynamic depression were not significantly different in this study and hemodynamic variability did not differ from the control group (Figure 1). No significant hemodynamic differences were observed during the surgery and in the postoperative period between the two groups. Similar results were found in the studies of Hwang et al, Agarwal et al, and Kahraman F, Eroglu A., 4,6,7

Need for first analgesic requirement per time to first pain (min) is presented in Table 3 . The time to first analgesic request was significantly longer in the magnesium sulphate infusion group in the study by Agarwal et al where need for first analgesic requirement was at $262.88 \pm 21.11 \mathrm{~min}$ in $\mathrm{Mg}$ group and $193.25 \pm 17.74 \mathrm{~min}$ in Non $\mathrm{Mg}(\mathrm{P}=0.04) .{ }^{6}$ Kumar et al also demonstrated that the duration of analgesia and the requirement of first rescue analgesia was longer in $\mathrm{Mg}$ group $(333.91 \pm 202.41)$ min versus $(232.68 \pm 140.62) \mathrm{min}$ in the control group with $\mathrm{P}$ value of $<0.05$. $^{9}$

Postoperative pain scores assessed by visual analogue scale and the results are depicted in Table 4. The pain scores were similar in both the groups between 24 to 48 hours. Similar results were also found in the study by Hwang et al and Vandana et al where in the Mg group at 4, 24, and $48 \mathrm{hrs}$ after surgery, postoperative VAS scores were markedly and significantly lower $(\mathrm{P}<0.001){ }^{4,10}$ Kahraman et al reported that the VAS scores were lower in $\mathrm{Mg}$ group than those in Non $\mathrm{Mg}$ group at $2 \mathrm{hrs}$ and $4 \mathrm{hrs}$ after the surgery. ${ }^{7}$ Kumar et al also found that postoperative pain scoring by VAS was much lower in the Mg group than Non Mg group. ${ }^{9}$ Meta analysis done 
by Albrech et al and stated that postoperative pain scores for 24 hours postoperatively was reduced by intravenous magnesium sulphate. ${ }^{11}$

The results of mean dosage of Tramadol consumption are presented in Table 5. It shows that mean dosage of Tramadol needed in first $24 \mathrm{hrs}$ was less in $\mathrm{Mg}$ group compared to the Non $\mathrm{Mg}$ group. In a study by Hwang et al, in Group $\mathrm{M}$ total postoperative consumptions of PCA were markedly lower at 4, 24 and $48 \mathrm{hrs}$ after surgery and during the postoperative period $(\mathrm{P}<0.001)$, more patients in the control group required additional rescue analgesia ( 2 vs 6 patients), but this was not statistically significant $(\mathrm{P}=0.079) .{ }^{4}$ Agarwal and associates found that in $\mathrm{Mg}$ group, mean dosage of Tramadol needed in first $24 \mathrm{hrs}$ was less compared with Non $\mathrm{Mg}$ group $(190 \pm 30.38 \mathrm{mg}$ versus $265 \pm 48.30 \mathrm{mg}, \mathrm{P}=0.000){ }^{6}$ The results of rescue analgesia required in patients are tabulated in Table 6 . The results showed that one patient in $\mathrm{Mg}$ group and 4 patients in Non $\mathrm{Mg}$ group required rescue analgesia, morphine $4.5 \mathrm{mg}$ intramuscularly. Kumar and co-workers reported as decreased mean postoperative rescue analgesia requirement (morphine) in $24 \mathrm{hrs}$ in $\mathrm{Mg}$ group $(3.99 \pm 1.25 \mathrm{mg})$ as compared to NS group $(7.13 \pm 2.68$ mg) (P value <0.006). ${ }^{9}$ Meta analysis by Albrecht et al reported that intravenous magnesium sulphate can reduce total postoperative opioid consumption. ${ }^{11}$

The incidences of postoperative nausea, vomiting and shivering after surgery are shown in Table 7 and were similar in both the groups. Hwang et al and Vandana et al also found that the incidence of postoperative nausea, vomiting and the incidence of shivering were similar in the two groups. ${ }^{4,10}$

\section{Limitations}

The inability to measure the serum magnesium level as well as the inability of use of patient control analgesia (PCA) for control of pain was the major drawback of this study. Minor side effects of parenteral magnesium such as nausea, headache and flushing are seen at serum magnesium levels above $2 \mathrm{mmol} / \mathrm{litre}$ and life-threatening adverse events involving the neuromuscular and cardiovascular systems occur at serum magnesium levels above $5 \mathrm{mmol} /$ litre. $^{12}$ In this study, no features of magnesium toxicity like depressed patellar reflex, decrease in respiratory rate, decrease in urine output or ECG changes like prolonged PR interval or wide QRS were noted in either groups.

\section{CONCLUSION}

This study reveals the effectiveness of perioperative intravenous infusion of magnesium sulphate in prolonging the spinal block as well as reducing the postoperative pain scores and postoperative analgesic requirements without significant hemodynamic variability or side effects. The observations of the study suggest that intravenous bolus $(50 \mathrm{mg} / \mathrm{kg})$ and infusion
$(15 \mathrm{mg} / \mathrm{kg} / \mathrm{hr})$ of magnesium sulphate is safe to use, it improves postoperative analgesia and reduces postoperative analgesic requirement after spinal anaesthesia without having any adverse effects.

Funding: No funding sources

Conflict of interest: None declared

Ethical approval: The study was approved by the Institutional Ethics Committee

\section{REFERENCES}

1. Koltka K, Uludog E, Senturk M, Yavru A, Karadeniz M, Sengul T, et al. Comparison of equipotent doses of Ropivacaine-Fentanyl and Bupivacaine-Fentanyl in Spinal anaesthesia for lower Abdominal Surgery. Anaesth Intensive Care. 2009;37(6):923-8.

2. Buvanendran A, McCarthy RJ, Kroin JS, Leong W, Perry P, Tuman KJ. Intrathecal Magnesium prolongs Fentanyl analgesia: a prospective, randomized, controlled trial. Anesth Analg. 2002;95:661-6.

3. Ryu JH, Kang MH, Park KS, Do SH. Effects of Magnesium sulphate on intraoperative anaesthetic requirements and postoperative analgesia in gynaecology patients receiving total intravenous anaesthesia. Br J Anaesth. 2008;100(3):397-403.

4. Hwang JY, Na HS, Jeon YT, Ro YJ, Kim CS, Do SH. IV infusion of Magnesium sulphate during Spinal anaesthesia improves postoperative analgesia. Br J Anaesth. 2010;104(1):89-93.

5. Malleswaran S, Panda N, Mathew P, Bagga R. Magnesium as an intrathecal adjuvant in mild precclampsia. Int J Obstet Anesth. 2010;19:161-6.

6. Agrawal A, Agrawal S, Payal YS. Effect of continuous Magnesium sulfate infusion on Spinal block characteristics: A prospective study. Saudi J Anaesth. 2014;8:78-82.

7. Kahraman F, Eroglu A. The effect of intravenous Magnesium sulfate infusion on sensory Spinal block and postoperative pain score in abdominal hysterectomy. Biomed Res Int. 2014;2014:236024.

8. Koinig H, Wallner T, Marhofer P, Andel H, Hörauf $\mathrm{K}$, Mayer N. Magnesium sulfate reduces intra- and postoperative analgesic requirements. Anesth Analg. 1998;87(1):206-10.

9. Kumar M, Dayal N, Rautela RS, Sethi AK. Effect of intravenous Magnesium sulphate on postoperative pain following Spinal anaesthesia, A randomized double blind controlled study. Middle East J Anaesthesiol. 2013;22(3):251-6.

10. Tyagi V, Rajendra A, Chaturvedi S, Chaudhri RS. IV infusion of Magnesium sulphate during Spinal anaesthesia to improve postoperative analgesia in patients undergoing lower extremity surgery. Journal of Evolution of Medical and Dental Sciences. 2013;2(25):4587-93.

11. Albrecht E, Kirkham KR, Liu SS, Brull R. Perioperative intravenous administration of Magnesium sulphate and postoperative pain: a meta-analysis. Anaesthesia. 2013;68(1):79-90 
12. Vissers RJ, Purssell R. Iatrogenic Magnesium overdose: two case reports. J Emerg Med. 1996;14:187-91.
Cite this article as: Revi N, Raju MP, Ali MM. Effect of intravenous infusion of magnesium sulphate on postoperative analgesia in patients undergoing arthroscopic knee surgeries under spinal anaesthesia. Int J Basic Clin Pharmacol 2017;6:2917. 